\title{
A novel method to determine respiratory system mechanics during assisted ventilation
}

\author{
D Schädler , T Becher, G Zick, I Frerichs, N Weiler \\ From ESICM LIVES 2015 \\ Berlin, Germany. 3-7 October 2015
}

\section{Introduction}

Knowledge of respiratory system mechanics during assisted ventilation is of high clinical interest. To date, it is only possible to measure it using an esophageal catheter or with the help of maneuvers using a specifically modified ventilator $[1,2]$.

\section{Objectives}

To assess the accuracy of a novel method to determine respiratory system mechanics during pressure-support ventilation in a prospective clinical study.

\section{Methods}

We included 20 mechanically ventilated patients. Respiratory system compliance was calculated by dividing the volume change induced by small changes in pressure-support level by the corresponding change in mean inspiratory airway pressure with subsequent adjustment for the pressure-support termination criterion (25\% of peak inspiratory flow). To determine the respiratory time constant $(\tau)$, every expiratory flow-volume curve was divided into ten slices of equal volume. $\tau$ was calculated as the mean value of the curve's slopes in every slice of one breath only in the breaths with linear flow-volume relationship. Respiratory system resistance was derived by dividing compliance by $\tau$. As a reference, we determined respiratory system mechanics measured during volumecontrolled ventilation with constant inspiratory flow.

\section{Results}

Correlation analyses showed a good correlation of compliance $(\mathrm{r} 2=0.74$; bias $-5 \mathrm{ml} / \mathrm{cm} \mathrm{H} 2 \mathrm{O})$, a moderate correlation for $\tau(\mathrm{r} 2=0.68$; bias $202 \mathrm{~ms})$ and a poor correlation for resistance $(\mathrm{r} 2=0.05$; bias $11.8 \mathrm{~cm} \mathrm{H} 2 \mathrm{O} / \mathrm{l} / \mathrm{s})$ when compared with the reference method.

University Medical Center Schleswig-Holstein, Campus Kiel, Anaesthesiology and Intensive Care Medicine, Kiel, Germany

\section{Conclusions}

We conclude that the proposed novel, non-invasive method for the assessment of respiratory system mechanics in assisted ventilated patients delivered proper values for compliance and respiratory time constant but not for resistance. Determination of reliable resistance values might require the use of additional methods.

Published: 1 October 2015

\section{References}

1. Younes M, et al: Am J Respir Crit Care Med 2001, 163:829-839.

2. Younes M, et al: Am J Respir Crit Care Med 2001, 164:50-60.

doi:10.1186/2197-425X-3-S1-A669

Cite this article as: Schädler et al:: A novel method to determine

respiratory system mechanics during assisted ventilation. Intensive Care Medicine Experimental 2015 3(Suppl 1):A669.

\section{SpringerOpen $^{\odot}$}

C 2015 Schädler et al.; This is an Open Access article distributed under the terms of the Creative Commons Attribution License (http:// creativecommons.org/licenses/by/4.0), which permits unrestricted use, distribution, and reproduction in any medium, provided the original work is properly cited.
Submit your manuscript to a SpringerOpen ${ }^{\circ}$ journal and benefit from:

- Convenient online submission

- Rigorous peer review

- Immediate publication on acceptance

- Open access: articles freely available online

- High visibility within the field

- Retaining the copyright to your article

Submit your next manuscript at $>$ springeropen.com 